\title{
HISTORICAL MEMORY AS A FACTOR OF NATIONAL IDENTITY FORMATION
}

https://doi.org/10.37096/SHDISJ-20-2.2-0006

\author{
Lytvynenko Oleksandr \\ ORCID ID: 0000-0002-0544-8977
}

\begin{abstract}
The article is devoted to the problems of historical memory formation as a factor of national identity formation. Its actuality is due to the serious challenges that exist in Ukraine for the Ukrainian national identity. These challenges are due to the long-term impossibility of developing our own historical discourse, regionalization of historical memories, politicization of historical issues. The comparative and structural-functional methods have mainly been used in this research. The first one is a comparative analysis of different interpretations of historical memory and national identity. The second has been used in determining the structure of historical memory and the directions of its influence on the formation of national identity. Historical memory became the object of the author's scientific interests in 2015. A more detailed study of the impact of historical memory on national identity was carried out in 2020 .

The article analyzes the phenomena of national identity and historical memory, the structure and functions of historical memory, its connection with history as a science have been analyzed in this article. The most significant and relevant, according to the author, problems of formation of historical memory in modern Ukraine have also been covered: 1) time gaps and deformations of this process; 2) the long impossibility, in fact, until the end of the twentieth century, of actualization in the public consciousness of one's own historical narrative; 3) significant regional differences in historical memories that lead to horizontal gaps in historical memory; 4) mental alienation of Ukrainians from a significant part of their history.

The discussion examines the critique ideas of essentialist about the nation and national identity, based on the concept of the nation as an "imagined community", reveals its theoretical shortcomings and political motivation. Arguments were also made against the call of some Ukrainian historians to abandon the national paradigm of historiography as one that allegedly leads to "provincialism" and "isolationism."

The importance of historical policy or the policy of memory for post-socialist countries, the urgency of the problems of historical memory for Western countries in the context of globalization and migration challenges have been emphasized in the conclusion.
\end{abstract}

Keywords: historical memory, historical narrative, national identity.

\section{Introduction}

The relevance of the topic of this article is due to several circumstances. First, the fact that Ukrainian national identity, even after thirty years of independent existence, remains a problem rather than a fact. Although, according to opinion polls conducted in 2017-2019, $92 \%$ of Ukrainians consider themselves as Ukrainians and $83 \%$ - patriots of their 
country, and according to the first indicator, Ukraine could even be considered as a mono-national state, there is a reason to believe that the concept "Ukrainian" and "patriot of Ukraine" many of them have completely different, often opposite meanings (Stepyko, 2020: 116-117). In addition, during these thirty years, the attitudes of Ukrainian citizens to the constitutive components of national identity have fluctuated significantly depending on the socio-economic situation in the country, real or imagined prospects for its existence, political crises, and even geopolitical changes. And most importantly, it is almost impossible to predict what changes in this area will occur in the future.

Secondly, the fact that historical memory has always played a special role in the socio-political life of Ukraine. Ukrainian political parties, in addition to such political relics and atavisms as the Communist Party of Ukraine, the Socialist Party of Ukraine, the Progressive Socialist Party of Ukraine, etc., and presidents differed not so much in their socioeconomic programs as in foreign policy orientations. . Thus, the European choice was accompanied by the actualization of historical ideas about Ukraine as a European country since the time of Yaroslav the Wise - "father-in-law of Europe", a grateful recipient of European culture in the Baroque era, an outpost of European civilization to threats from the East. The course of rapprochement with Russia was based on the common historical past since Vladimir's baptism, the prominent role of Ukrainians in building the Russian Empire and the Soviet Union, their participation in the wars and victories of these state formations, peace and prosperity won by Ukraine under Moscow. Less common focus solely on their own forces, rather than on West or East, drew inspiration from memories of the glorious Trypillia, Aryan, Scythian and Proto-Slavic past, when there was no Europe, much less Russia, and the ancestors of Ukrainians already were and amazed the world with their military power, cultural brilliance and human virtues.

Thus, the future of Ukraine is seen by those on whom it largely depends political elites - through the prism of history, as it seems to them, constructed on the basis of personal life experience, socio-cultural context of their existence, interests, external influences.

Thirdly, which follows from the previous one, historical memory, like Ukrainian identity, is an extremely heterogeneous and unstable phenomenon, dependent both in terms of content and institutions on the political situation, differentiated according to regional historical and cultural divisions. In 2014, in some regions, the lines of these divisions became the lines of armed confrontation. According to a historian O. Zaitsev, "one of the important factors that allowed Putin to ignite the war was historical memory divided in Ukraine and much more united and imbued with imperial myths in Russia" (Zaitsev, 2015).

Fourth, in the modern world there is a tendency to gradually eroade national identity in favor of strengthening the sense of belonging of individuals to other - sub- or supranational - social entities. Moreover, this affiliation can be variable, in any case, it is not imperative, as it was in times of clear estates, cultural, religious boundaries. This situation leads to a crisis of national identity, which makes the 
future of the nation itself and its organizational form - the state. The fact that this problem concerns not only Europe - the homeland of classical nations and national movements, as evidenced by the work of S. Huntington "Who are we? Challenges to American National Identity" (Huntington, 2018). Therefore, the choice of effective means of national socialization is a priority issue of national security, especially in countries where the state is still in its infancy and has problems with creating effective safeguards against national destruction.

Based on this, it can be argued that the future of Ukraine as a sovereign, politically stable and economically developed state depends not only on reforms in political, economic, administrative and other spheres, but above all on the formation of common historical memory for all its citizens. identity, without which neither lasting national consolidation nor internal national solidarity is possible.

The aim of the article is a theoretical analysis of the problems of formation of historical memory as a factor in the formation of national identity.

\section{Theoretical background}

Numerous works of foreign scholars are devoted to the problems of historical memory, in particular, A. Assman (Assman, 2012), R. Kozellek (Kozellek, 2005), P. Reeker (Riker, 2004), J. Rusen (Rüsen, 2010). E. Smith (Smith, 2009) analyzed and in some way systematized all the diversity of ideas about the nation, the factors of its formation, the historical framework of its existence. T. Snyder studied the formation of national identities in Ukraine and its historically associated Poland, Lithuania, Belarus. E.
Hobsbawm (E. Hobsbawm, 2010) and B. Anderson (Anderson, 2001) - the role of "invented traditions" and the collective imagination in the formation of national identities. P. Nora (Nora, 2014) - the specifics and functions of collective memory in modern Western society.

In Ukraine, the problems of formation of historical memory and the formation of national identity were studied, in particular, by E. Bystrytsky, Y. Zerniy, L. Nagorna, G. Kasyanov, M. Stepyko and others. N. Yakovenko, Z. Kohut, S. Plohiy devoted their works to the formation of Ukrainian identity in the early and modern periods of national history. S. Krymsky analyzed the archetypes of the Ukrainian national consciousness in the context of the formation of traditional culture. M. Rozumny researched the mentioned problems in the context of the information society.

Paying tribute to the scientific achievements of the above-mentioned researchers, we consider it necessary to determine our own theoretical positions on the subject of this article. In our opinion, it is expedient to consider the nation, national identity, historical memory not as separate phenomena, but in a complex, in their dialectical interrelation, as parties of one social essence. This is not a tribute to the systemic approach popular in modern research, but a methodological necessity, because differentiation and specialization in the study of these phenomena may lead not to clarification but to distortion of their vision, and in accordance with onesided conclusions, as we will try to show below.

Also, in understanding the phenomenon of the nation, we share the position of Perennialism (according to the 
classification of E. Smith), that is, do not draw a clear line between ethnic and national and do not consider the nation works of political and intellectual elites of the modern era. In our opinion, the nation is only a stage in the organic development of the ethnos in the conditions of modernism, so to speak, a political metamorphosis of the ethnic. From this point of view, the artificiality and politicization of the division of nations into "political" and "ethnic" becomes obvious, with the recognition of perspectives and moral advantages only by the former. Moreover, only the recognition of the historical depth of national existence gives real meaning to the study of historical memory and national identity, because only in this case do they look like something essential and not artificially constructed. In the latter case, they should be the subject not of scientific consideration, but of politicaltechnological manipulations.

\section{Methodology}

The study used mainly comparative and structural-functional methods. The first is a comparative analysis of different interpretations of historical memory and national identity. The second is in determining the structure of historical memory and the directions of its influence on the formation of national identity and collective consciousness.

\section{Results}

History occupies a special place among the sciences in their relation to man. It does not create the preconditions for the invention of new, better means of its existence, does not expand the possibilities of its knowledge of the universe. It is a source of self-knowledge of man as an individual and as a community. Like any knowledge, historical knowledge needs to be generalized. However, this generalization occurs in a special way - not at the conceptual-categorical, but at the figurative-sensory level (if it is appropriate to talk about levels). Historical images allow a person to understand something in himself, his past and present. To do this, they must turn from facts into symbols, in extreme cases - into archetypes of individual and community existence. It is in this perspective that history can serve as a "landmark of the highest order in human life," as defined by J. Rusen (Rusen, 2010: 9). Thus, historical self-knowledge intersects with socio-cultural selfidentification (identification).

Although it is believed that the concept of "identity" was introduced into social psychology in the middle of the last century by E. Erickson and A. Goldner (Bystritsky, 2015: 11), but we must recognize that the phenomenon of identity existed long before the articulation of its concept, probably since the emergence of "intelligent man". Similarly, national identity, which became the subject of scientific research and public interest only in the twentieth century, has existed since the emergence of nations. This process in England since the XVI century., France since the XVII century., Russia and the United States since the XIX century. described in detail by L. Greenfeld in her fundamental work "Nationalism", but in general the origin of nations, as well as the time and conditions of their emergence, remains controversial in modern science (Greenfeld, 2012).

Speaking of national identity, we cannot ignore the question of defining a nation. However, it is also so debatable that some researchers consider it impossible in principle to give the nation a comprehensive universal definition. E. 
Renan in his essay "What is a nation?" noted that all its objective characteristics, such as race, language, religion, culture, geographical area of common interests, are relative. A nation is a soul or a spiritual principle that consists of two things: "One is the common possession of a rich heritage of memories, the other is the common consent, the desire to live together, to enjoy a common and further indivisible heritage... Heroic past, great people, glory (but fair) - this is the main capital on which the national idea is based. To have common glory in the past, common desires in the future, to perform great deeds together, to desire them in the future - these are the main conditions for being a nation. However, at the beginning of his essay, Renan says something else: "Forgotten history, or rather, historical error is one of the main factors in the creation of a nation, and therefore the development of historical research is often dangerous for nationality," because historical research "sheds light on violence. which were at the beginning of all political works, even those that had very beneficial consequences" (Renan, 2000).

Thus, constitutive for the nation, according to E. Renan, are not objective characteristics, but subjective factors memory and desire to be. The first is an element of her self-knowledge, that which creates for her her own image, the second - the will to continue its existence in the same capacity, in the same image, in other words - to maintain its dynamic identity.

It is necessary to recognize a certain validity of this, at first glance, somewhat idealistic point of view. Although traditionally the most obvious components of national identity are not only the common historical heritage and collective memory, but also language, culture, spiritual connection with the territory of formation and existence of the nation, but given the historical nature of language, culture and ideas of the nation as her homeland, we can say that national identity is constituted primarily by the attitude to national history to the formative factor. Even the opposition "we - they", fundamental for the formation of national consciousness, did not arise suddenly, but was formed historically. Both "we" and "they" are endowed with certain characteristics, but these characteristics are not immanent. They carry the whole historical heritage of the relationship between "us" and "them" and exist only in this relationship. In addition, a nation may survive even after losing its statehood, territory, socio-political and cultural institutions and even language, but it ceases to exist after losing its historical memory as the basis of national self-consciousness and the will to be based on that self-consciousness.

At the same time, this point of view has certain limitations. After all, common historical memory, "joint possession of a rich legacy of memories", retains a consolidating and suggestive power as long as it is based on a very specific subject area - territory ("homeland"), which must be returned to national ownership or to which to return, culture, which needs to be revived, including in its material and material manifestations, the language and religion of ancestors, which also need to be preserved or revived, etc. Correcting the previous statement, we can say that the people begins to assimilate and disappear as a historical subject not when it loses historical memory, but when its content loses its meaning and prospects, unconditionally remaining in the past without any hopes for discovery, 
revival in a completely objective, material form in the future.

Historical memory as a factor of the national identity formation - differs from history as a science, which aims to objectively study the past, regardless of political goals and circumstances. According to J. Rusen, historical memory is "the vitality and effectiveness of a culturally conditioned and constantly updated interpretation of the past in the culturally oriented framework of the modern life of specific subjects. It is normatively oriented and tends to interpret the past in terms of its usefulness for the present. Then historical consciousness, as an excellent way of interpretation, points more to the control of experience and the critical distancing of historical knowledge from the legitimating requirements of modernity" (Rüsen, 2010: 20-21).

The goal of historians is to bring back from oblivion the events of the past, no matter how unfortunate they may be for national selfishness. The goal of the creators of historical memory is to give the nation a picture of the past that is acceptable in terms of maintaining national dignity, the needs of further development and increasing competitiveness in the international arena. As such, historical memory tends to become a national myth. Mythologizing history is not so much about inventing non-existent or giving hypotheses the status of real facts, but about endowing real historical characters and events with subjectively conditioned, emotionally colored value characteristics, deliberately exaggerating or diminishing their significance, glorifying their heroes and demonizing or demonizing the past as the "golden age" or the time in which the glorious ancestors acted, laying the material and spiritual foundations of the nation.

However, this distinction is quite conditional. As J. Rusen wrote above, "memory, which is not based on experience, not on the content, the existence of which is at least assumed, loses its orientation in life, and knowledge of what happened in the past has a special property" historical "Only when it speaks of the importance of the known for the cultural orientation of modernity" (Rusen, 2010: 21).

It is no coincidence that historiography flourished in the 19th century, the century of nationalism, when new political nations were formed in Europe on the basis of old ethnic groups and models of national emancipation were created, combining political, religious, social and cultural elements. It was a time of creating great historical narratives that put nations in front of images of their past, where they found a source of inspiration and justification, a treasure trove of role models. Thus, historiography became an important factor in the formation of national identity. It is noteworthy that the French historian P. Nora, a postmodernist and critic (or rather a follower of critics) of "great narratives" in historiography, recognizes, speaking of classic examples of these narratives - a school textbook on French history and 27-volume "History of France". "Although the content (of these works) has long been obsolete, we have long, for a century, lived in France and a world that has little to do with the national consciousness and republican optimism that follows from these textbooks, as well as from this" History ", But all of us, as 
historians, as French, as citizens, have Lavis in our blood" (Nora, 2014: 127).

Historical memory, as the basis of national identity, has a multilevel character. It is formed under the influence of: 1) national historical narrative; 2) regional historical narratives; 3) "microstories" of communities; 4) family "micro-stories". Under normal circumstances, local and family historical memory become a memorial "microcosm" in which, with appropriate refraction, the "macrocosm" of national memory is reflected. However, this ideal scheme does not always have exact equivalents in real life. There are many cases when these levels of influence are in conflict with each other, forming, as a result, an internally contradictory worldview. For example, regional historical narratives can claim the status of national or become the basis of irredentist sentiments.

The means of forming / preserving historical memory are quite diverse. The main ones include: scientific historical works, normative textbooks, popular science historical works, memoirs, historical fiction, audiovisual historical works (both popular science and art), mass media, tangible and intangible cultural heritage, oral histories, folklore, formal and informal commemorative events, in a sense and under certain conditions - religious traditions.

The functions of historical memory include: first, the creation of a holistic image of the nation in its historical development (the past is a mirror in which people can see themselves and on the basis of what they see form a certain opinion about their own historical destiny); secondly, the consolidation of society, increasing its resistance to negative external influences and interference, which is achieved through the strengthening of national identity; third, to settle the nation's reckoning with its own past in such a way that it opens the prospect of a kind of catharsis overcoming historical complexes, moral justification or apology for contradictory actions in the past.

These functions can be quite effective only if there is a perspective of a certain future, and the clearer the idea of the desired future, the more specific the requirements for historical memory. Conversely, the uncertainty and illusory nature of the future force man to hold on to the present as the only possible reality. The past no longer weighs on the individual and society - it becomes a treasure trove of "just" facts, examples, signs, allegories and just "curiosities", but loses its motivation.

The problems of historical memory formation in Ukraine. The formation of the historical memory of the Ukrainian people was not a continuous process. It is characterized by long time gaps and deformations, due primarily to the long stay of most, and since 1945, the whole of Ukraine as part of the Moscow Empire, the Russian Empire and their historical successor, the Soviet Union. All these state formations were dominated by views of Ukrainians as part of the Russian people or as a blood-related "brotherly" people who were destined to be with the Russians in the same state. Accordingly, any attempts not only to politically separate Ukraine from Russia, but also to form its historical subjectivity, to prove its separation from the Russian language, culture, and history were perceived extremely negatively by the Russian establishment and qualified as separatism. 
As a result, the process of creating Ukraine's own great historical narrative was delayed compared to similar processes in other European nations, and this narrative itself became the property of the general Ukrainian public only in the late 80 's - early 90 's of the twentieth century. Until now, its components are the works of M. Hrushevsky, D. Doroshenko, N. Polonska-Vasylenko and others were available to the Ukrainian reader only in the diaspora, and in Ukraine their concealment and distribution were considered a criminal offense.

This does not mean that Ukrainians did not have a historical memory during their stay in the mentioned states. It existed, and in Soviet times it was formed extremely actively and purposefully under the influence of Russian historical narratives, the specifics of which in relation to Ukraine were mentioned above. Under the influence of this memory, Ukrainians formed the idea of their people as secondary and inferior to Russia, of most heroes of national liberation struggles - as traitors and criminals, of their culture - as immature and provincial, secondary to Russian culture. The influence of historical officialdom was partly offset by oral history, family memories, and so on. However, firstly, these memories differed significantly in content depending on the regions, secondly, a significant part of them, especially traumatic, was transformed or replaced by memory in the process of psychological compensation, and thirdly, in the face of official historical memory. These memories created a cognitive dissonance that not everyone was able to withstand, and therefore preferred to focus on the version learned in school, approved by the government and supported by the conclusions of nationalized historical science.

As a result, different versions of historical memory still exist and have a significant impact on the public consciousness in Ukraine, and not only different, but often hostile to each other. This is especially true of the interpretation of such historical events as the Holodomor of 1932-1933, the national liberation struggles of the twentieth century, and the Second World War. This greatly complicates the tasks of both historical science and historical or memory policy in Ukraine. If, for example, in modern Russia the newly constructed historical memory was to eliminate, so to speak, the "vertical" gaps created in Russian history by the revolutions of 1917 and the liquidation of the USSR in 1991 (a similar task was facing French historiography of the XIX century.), then Ukrainian historical science and the policy of memory face a slightly different and more difficult task to eliminate the "horizontal" gaps in national history. The greater complexity and danger of "horizontal" gaps, compared with "vertical", is that they contribute in their extreme manifestations to the formation of different identities. "Vertical" gaps only lead to disputes over the identity of the same nation.

These disputes, no matter how sharp and long, are sooner or later overcome either by the creation of a national historical narrative, where there is a worthy place for heroes, deeds and institutions of all periods of national existence (the case of France in the Third Republic), or by political discourse on revival. National and state greatness, which in itself removes the contradictions of the past, because greatness and prosperity have always been the goal of 
the state, regardless of the state system (the case of modern Russia). Both in the national historical narrative and in the political discourse, "vertical" historical gaps (changes in the state system, liquidation of entire social classes, multimillion victims of civil wars and political repressions) can be presented as painful but necessary stages of national development, because any development occurs due to the emergence of contradictions and their overcoming, "removal".

Some scholars, in particular, L. Nagorna, V. Rasevych, V. Soldatenko, V. Babka, etc., a significant shortcoming of the Ukrainian historical memory, and, accordingly, the memorial policy. to the emergence of depressed social sentiments, a complex of historical inferiority, and so on. Examples of such victimization are the historical policy of President Yushchenko, in which considerable emphasis was placed on honoring the victims of the Holodomor, political repression, the Baturyn massacre, and the tragically killed heroes of the liberation struggle (Babka, 2016: 119-120).

In our opinion, the problem of Ukrainian historical memory is not the pathos of tragedy and victimhood, generated by the long history of military defeats, national and social oppression. This pathos, like the cult of national suffering, is no less, if not more, present in the historical memory of the Jewish and Armenian peoples, but for them it serves as a source not only of sorrow (and by no means despair) but also of national consolidation. and resistance to external challenges. Visiting the memorial on Tsitsernakaberd Hill near Yerevan on April 24, dedicated to the victims of the 1915 genocide, annually becomes a nationwide commemorative event for Armenian citizens, which does not depress the people's spirit, but on the contrary, elevates it. The same can be said about the visit of Israeli citizens and Jews from the diaspora to the Yad Vashem memorial complex in Jerusalem. As E. Renan wrote, "Common suffering unites more than common joys. In national memories, sadness is more important than triumph: sadness imposes responsibilities, sadness encourages joint efforts."

The problem of Ukrainians is not the tragic national history, which allegedly frustrates their consciousness and instills in it pessimism about the present and the future, but their largely artificial, but still insurmountable, mental alienation from much of this history. As a result, many undoubted victories, examples of heroism, cultural achievements, even when made public, have not become part of the national historical memory, a formative factor of national identity. M. Stepyko, also noting that "the specificity of the existence of Ukrainian society and its historical memory is that they are dominated by social pessimism, pathos of tragedy and victimhood", quite rightly connects the first of these phenomena with the complex of "Little Russia": Social pessimism, total capitulatory sentiments are a distinctive feature of Little Russia, which is still widespread in Ukraine. its transformation depending on the degree of pressure of society" (Stepyko, 2020: 148).

\section{Discussion}

In modern, including Ukrainian, science is quite popular critique of the "essentialist" understanding of the nation as a certain socio-historical entity and, accordingly, the understanding of identity as a characteristic of the existence of a 
national-cultural community as a single organism, when identity becomes an individual, and an individual becomes an identity" (Bystrytsky, 2015: 30). According to B. Anderson, a nation is understood as an "imagined community" and identity as an "imagined way of being", and judgments about it are "fundamentally different from those that we can rationally justify" because they are based on prejudices that they do not need special proofs, just as they cannot be rationally proved" (Bystrytsky, 2015: 27$31)$. The essence of these prejudices is to "transform the collective preunderstanding" into a predetermined picture of the world, the knowledge of the characteristics of which gives us, as it were, a universal opportunity to judge everything in the world as simply as we obviously judge things. This understanding of identity limits the free choice of the perspective of the development of the nation and the individual: "Identity, which opens existential possibilities, turns into a total prejudice that restricts our freedom" (Bystrytsky, 2015: 32-33). In addition, an essentialist understanding of national identity leads to a policy of nonrecognition of the "other" and, in extreme cases, violence against him.

It is noteworthy that in her speech at the conference "The Holocaust in Ukraine: New Sources and Prospects" (2013), Professor Sorbonne Delfin Bestel accused Ukrainian researchers, in addition to "Ukrainocentrism", of "belief in essentialism when individuals are viewed through the prism of collective group psychology.", which, in her opinion, does not meet Western standards of scientific research (Bechtel, 2013).

In view of the above, it should be noted that "imagination" can be considered a characteristic of any social phenomenon, including man as a social being, and if we follow Schopenhauer, then the whole world. Similarly, in history we are not dealing with what was "really", in the understanding of Leopold von Ranke, but with the idea of him. However, such ideas are not identical with unfounded fantasies or reckless optimism and do not deny the reality and objectivity of "imagined" phenomena. In this case, we are dealing, on the one hand, with the hypostasis of quite obvious characteristics of the reflection of reality, including social, in the human psyche, and on the other, with the illegal politicization of a particular case of the problem of objective reality and its mental reflection.

In addition, national identity is only one of human identities and does not claim to form a universal worldview. Also, identity can limit "our freedom" only in the sense in which it is limited by an objective necessity consisting of our physical data, the natural and social conditions of our existence, and so on. As for the biased, negative attitude towards the "other", it is not embedded in the essentialist understanding of the nation, and not in the understanding of national identity as an objective fact with permanent characteristics, but in the instrumental use of the first and second for political purposes. But no social phenomenon, no value system, no idea is safe from such use. It can be assumed that both theoretical and practical deconstruction of the national with all its attributes, and the erosion of traditional identities and the formation of "hybrid" identities may lead in the future to no less tragic consequences than the extremes of nationalism.

Ukrainian historians are increasingly proposing to go beyond the national 
paradigm in historiography. According to S. Plohi, "writing national history in modern conditions means strengthening isolationism and provincialism in Eastern European historiography... The new nations of Eastern Europe want to be part of a united Europe, and their young historians seek to find their place among the European and world historical community" (Bad, 2013: 5). Instead, a transnational approach is proposed, in which Ukraine is seen "as a civilizational and cultural border. That is, both as a dividing line and a bridge between Central and Eastern Europe" (Plohiy, 2013: 10). It is noted that this approach has been successfully used in other Central and Eastern European countries, including Hungary and Poland. The funny thing is that with this approach, Ukraine will look like a bridge to at least two other bridges, and if this approach is applied in Western European historiographies, we will have a surreal picture in general. It should be noted that "frontal" studies are one of the promising areas in modern science. Such research is being conducted in Ukraine as well, but the history of the steppe front is only a part of the national history, many important events and processes of which did not take place at the border. Accordingly, the history of Ukraine cannot be reduced to, of course, important intercivilizational and intercultural ties. As for "provincialism" and "isolationism" as a consequence of national historical studies, in our opinion, they may be the result not of choosing the subject of study as such, but of inadequate assessment of its place and role in human history or a particular region. (-centrism, including "Eurocentrism").

In our opinion, research within the national paradigm does not in any way contradict Ukraine's desire to become part of a united Europe, and Ukrainian historians - to find their place among the European and world scientific community, unless, of course, environmental considerations. Only by knowing and comprehending one's own past and forming a stable identity on this basis can one hope to take a subjective position in Europe and the world, especially since Ukraine's neighbors are mostly nations with clearly articulated identities, developed historical consciousness and extremely respectful, even passionate to its own history.

In our study, we only briefly outlined the problems of the formation of historical memory in Ukraine. In the future, we consider it necessary to analyze these problems in more detail and describe in more detail the functional relationship between historical memory and national identity, as well as to carry out a comparative analysis of memory policy in Ukraine and European countries.

\section{Conclusion}

Historical memory is an important, if not the main factor of national identity and as such is the object of historical or memory policy both in Ukraine and in some other countries that were once part of the Soviet Union or the socialist camp and for which settlements with one's own past are a means of creating acceptable prospects for the future.

In Ukraine, the formation of historical memory, as well as the formation of national identity, was a complex, intermittent and quite painful process, which in our time is still far from completion, ie the development of Ukrainian society a common vision and evaluation of its own past, especially recent history. 
The problems of historical memory are also relevant for Western countries (Western Europe and the United States), whose identity, formed long ago and on a solid foundation of their own states with a long and glorious history, met in the late twentieth - early twenty-first century. with serious challenges and whose historiography, according to Western scholars, is in crisis. However, the latter circumstance is characteristic of the development of historical science in the last hundred years and can be seen as an incentive to invent new approaches to solving existing problems, improve methodology and increase the social significance of history and historical memory.

\section{References}

Assman, A. (2012). Prostory spohadu. Formy ta transformatsii kulturnoi pamiati. [Memory spaces. Forms and transformations of cultural memory.]. Kyiv: Nika-Tsentr. (in Ukrainian)

Anderson, Benedykt. (2001). Uiavleni spilnoty. Mirkuvannia shchodo pokhodzhennia y poshyrennia natsionalizmu. [Imaginary communities. Reflections on the origin and spread of nationalism.]. Kyiv: Krytyka, 2001. (in Ukrainian) Babka, V. (2016). Istorychna pamiat yak faktor politychnoho vplyvu $v$ nezalezhnii Ukraini. [Historical memory as a factor of political influence in independent Ukraine.]. (Dys. kand. polit. nauk.). Nizhynskyi derzhavnyi universytet imeni Mykoly Hoholia, Nizhyn. (in Ukrainian)

Bechtel, Delphine. (2013). The 1941 Pogroms as Represented in Western Ukrainian Historiography and Memorial Culture. The Holocaust in
Ukraine: New Sources and Perspectives Conference Presentations. Center for advanced Holocaust studies. United States Holocaust memorial museum.

Bystritsky, E., Proleev S., White O., Loznitsa S., Zymovets R., Kobets R. (2015). Natsionalna identychnist $i$ hromadianske suspilstvo. [National identity and civil society.]. Kyiv: Spirit and Letter. (in Ukrainian)

Greenfeld, Leah. (2012). Natsyonalyzm. Piat putei $k$ sovremennosty. [Nationalism. Five ways to the present.]. Moscow: PER SE. (in Russian)

Hobsbawm, E., Ranger T. (Eds.). (2010). Vynaidennia tradytsii. [Invention of tradition.]. Kiev: Nika-Center. (in Ukrainian)

Hrytsak, Ya. (2010, December 2). Novi povoroty $v$ ukrainskii politytsi pamiati. [New turns in the Ukrainian politics of memory.]. Zakhid.net. Retrieved from: https://zaxid.net/novi povoroti v u krayinskiy polititsi pamyati n1117 $\underline{51}$

Kasianov, H., Tolochko, O. (2012). Natsionalni istorii ta suchasna istoriohrafiia: vyklyky ta nebezpeky pry napysanni novoi istorii Ukrainy. [National histories and modern historiography: challenges and dangers in writing a new history of Ukraine.]. Ukrainskyi istorychnyi zhurnal. 6, 4-24. (in Ukrainian)

Khantynhton, Samiuэl. (2018). Kto mbl? Vblzovbl amerykanskoi natsyonalnoi ydentychnosty. [Who are we? Challenges of American national identity.]. Moskva: AST. (in Russian)

Kohut, Zenon. (2004). Korinnia identychnosti. Studii $\quad z$ 
rannomodernoi ta modernoi istorii Ukrainy. [The roots of identity. Studies in early modern and modern history of Ukraine.]. Kyiv: Krytyka. (in Ukrainian)

Kozellek, Rainhart. (2005). Mynule maibutnie. Pro semantyku istorychnoho chasu. [Past future. On the semantics of historical time.]. Kyiv: Dukh i litera. (in Ukrainian)

Krymskyi, S. B. (2008). Pid syhnaturoiu Sofii. [Under the signature of Sophia.]. Kyiv: Vyd. dim «KyievoMohylianska akademiia». (in Ukrainian)

Nahorna, L.P. (2012). Istorychna pamiat: teorii, dyskursy, refleksii. [Historical memory: theories, discourses, reflections.]. Kyiv: IPiEND im. I.F. Kurasa NAN Ukrainy. (in Ukrainian)

Nora, Pier. (2014). Teperishnie, natsiia, pamiat. [The present, the nation, the memory.]. Kyiv: TOV «Vydavnytstvo «Klio». (in Ukrainian)

Plokhii, S. (2013). Yakoi istorii potrebuie suchasna Ukraina? [What kind of history does modern Ukraine need?]. Ukrainskyi istorychnyi zhurnal. 3, 412. (in Ukrainian)

Renan, Ernest. (2000). Shcho take natsiia? [What is a nation?]. O. Protsenko, B. Lisovyi (uporiad.) «Natsionalizm» (Antolohiia). (s. 107-120). Kyiv: «Smoloskyp» (in Ukrainian)

Riuzen, Yorn. (2010). Novi shliakhy istorychnoho myslennia. [New ways of historical thinking.]. Lviv: Litopys (in Ukrainian).

Rozumnyi, Maksym. (2006). Ideia $i$ natsiia $v$ informatsiinu epokhu: monohrafiia. [The idea and the nation in the information age: a monograph.]. Kharkiv: Maidan. (in Ukrainian)

Rykër, P. (2004). Pamiat, ystoryia, zabvenye. [Memory, history, oblivion.]. Moskva: Yzdatelstvo humanytarnoi lyteratur. (in Russian)

Smit, Entoni D. (2009). Kulturni osnovy natsii. Iierarkhiia, zapovit $i$ respublika. [Cultural foundations of nations. Hierarchy, testament and republic.]. Kyiv: Tempora. (in Ukrainian)

Stepyko, M. T. (2020). Ukrainska identychnist $u$ hlobalizovanomu sviti. [Ukrainian identity in a globalized world.]. Kharkiv: Maidan. (in Ukrainian)

Yakovenko, Natalia. (2012). Dzerkala identychnosti. Doslidzhennia $z$ istorii uiavlen ta idei v Ukraini XVI - pochatku XVIII stolittia. [Mirrors of identity. Research on the history of ideas in Ukraine in the XVI - early XVIII centuries.]. Kyiv: Laurus. (in Ukrainian)

Zaitsev, O. (2015, liutyi 26). Viina $i$ vidpovidalnist istorykiv. [War and the responsibility of historians.]. Lviv: Ukrainskyi katolytskyi universytet. Retrieved from: https://ucu.edu.ua/news/oleksandrzajtsev-vijna-i-vidpovidalnististorykiv-zahid-net/

Zernii, Yu. O. (2009). Derzhavna polityka pamiati yak chynnyk utverdzhennia ukrainskoi natsionalnoi identychnosti. [State policy of memory as a factor in establishing Ukrainian national identity.]. (Dys. kand. polit. nauk). Natsionalnyi instytut stratehichnykh doslidzhen, Kyiv (in Ukrainian). 